\title{
STUDENTS' PERCEPTION ON THE EFFECT OF ONLINE LEARNING DURING COVID 19
}

\author{
Dawi Yanti ${ }^{1}$ \\ ${ }^{1}$ STT Migas Balikpapan \\ Email:wieaurora@gmail.com
}

\begin{abstract}
The educational system across the world has been affected due to outbreak of Covid-19 pandemic, this new phenomenon forced teachers and students to do teaching and learning process from home. The purpose of writing this study was to investigate the students' perceptions of online learning has been implemented and the factors that influenced these perceptions. The instrument to collect the data was a questionnaire distributed using google form. The participants, 60 students of Sekolah Tinggi Teknologi Migas, filled the survey online to convey their perception on the effect of online learning during Covid-19. The finding of this study revealed that students positively accepted this new learning system although they have found some problems such as difficulty in using application and lack of the internet connection.
\end{abstract}

\section{Keywords: Students' Perception, Online Learning, The Covid-19}

\section{INTRODUCTION}

The phenomenon of COVId-19 pandemic has made the largest disruption for the system of teaching and learning process history. In 2020, the United Nations stated that Covid-19 was affecting nearly 1.6 billion learners in more than 190 countries and all continents, closures of schools and other learning spaces have impacted 94 percent of the world's student population. Corona virus outbreak has impacted the education sector, this pandemic caused educational gaps for children, teenagers, or adults. They are encouraged to do learning from home, including Indonesia's education sector.

The closure of schools and school activities from primary to university level thorough Indonesia was also affecting STT-Migas Balikpapan, students were required to learn online from home because of the cessation of direct learning face to face in class to break the chain and exposure to the corona virus. The government across nations emphasized and encouraged the use of online resources to support students (Hasan \& Khan, 2020). 
Online learning is an option for conducting teaching and learning activities at home, this situation requires students and teacher to implement a suitable technology for online learning. The reasons of this adequacy are easy to used, learning adaptability and controllable environment. (Green \& Hannon, 2007) said that most of learners have their empowered gadgets such as individual computers and mobile phones. They are utilizing these advanced gadgets for communication over formal and informal platforms of networking such as emails, blogging, etc. Some educators are exploring the use of more technologies such as mobile technologies, Moodle, WebCT or Blackboard to create hybrid course (Rodriguez et al., 2008)

There are some studies performed by researchers on the performance of online learning during Covid-19 pandemic. (Sari et al., 2020) found that student's perception of online learning used varied media or application in course has a good category for implementation. Online learning was very helpful, even not entirely (Sujarwo et al, 2020). Different from Sari and Sujarwo, (Susila et al., 2020) said that some students got lack of the internet connection during online learning. In addition to Susila, (Nasution \& Ahmad, 2020) discovered that students encountered difficulties in internet access, in communicating with lecturers, and in doing and collecting assignments when doing leaning online.

\section{Students' perspective}

In teaching-learning activities, students' perceptions give positive impact on the quality of interaction and communication. It is indicated that if the individual has a good view of something or other people, it will also benefit him/herself. Perception can also be considered an individual's interpretation of something (Amir et al., 2020). Perception is conveyed in the form of idea or action, human idea based on their experience. (Blake \& Sekuler, 2006)

\section{Online Learning}

Online Learning is a form of education where students use their computer or hand phone through internet. It is becoming popular during Covid-19, most country in the world using online learning. Nambiar (2020) stated that online learning and classes are increasingly becoming part of the education system worldwide. Online channel has made education convenient and accessible by one and all. Online learning is a process teaching learning use some tools like Zoom, Whatsapp, Googlemeet etc (Singh \& Thurman, 2019). Technological developments have led to more applications that support online learning, such as WhatsApp, google meet, google classroom, zoom, and Edmodo. Nasution \& Ahmad (2020). Similarly Hasan \& Khan (2020) continued wheels of learning, institutions, are switching to online mode of teaching and learning. The apps they used of video conferencing platforms such as WebEx, 
ZOOM, Google Meet, Say Namaste, as well as learning management systems like Moodle, Blackboard etc.

There are some studies performed by researchers on the performance of online learning during Covid-19 pandemic. (Sari et al., 2020) found that student's perception of online learning used varied media or application in course has a good category for implementation. Online learning was very helpful, even not entirely (Sujarwo et al, 2020). Different from Sari and Sujarwo, (Susila et al., 2020) said that some students got lack of the internet connection during online learning. In addition to Susila, (Nasution \& Ahmad, 2020) discovered that students encountered difficulties in internet access, in communicating with lecturers, and in doing and collecting assignments when doing leaning online.

In addition to those previous findings, this study aims at investigating the students' perception on their online learning during COVID-19 pandemic. Meanwhile, the mentioned perspective could be an input for lecturers and institutions to improve online learning quality. Thus, the purpose of this study is to know the students' perception on the effect of online learning during Covid-19

\section{METHOD}

The method of this study was a qualitative descriptive by focusing on survey to know the students' perception on the effect of online learning during Covid-19. Gunawan, 2017 in Sujarwo, et al (2020) stated that Survey techniques are used to gather information from a number of people about a particular topic or issue. The number of populations were 60 second semester students of D3 Teknik Instrumentasi and Elektronika Migas and D3 Teknik Pengolahan Migas 2019/2020. The instrument in this study was a questionnaire that was obtained by google form. A questionnaire was utilized to collect data from sample to describe about perspective of using online learning during Covid-19. The questionnaire consisted of 12 questions adopted from Nasution \& Ahmad (2020), as open-close-ended questionnaire. The analysis data was obtained by google form by analyzing participants' respondents to know their perspective to use online learning, in order to obtain data needed, then data were analyzed and describe to obtain answer to questions. 


\section{FINDING AND DISCUSSION}

1. Online learning is following current conditions 58 tanggapan

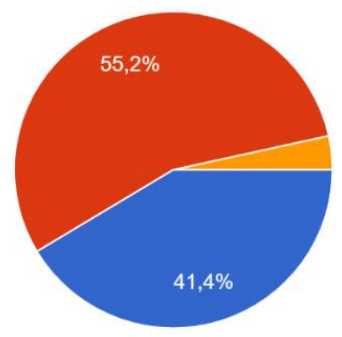

Strongly Agree

Agree

Disagree

Strongly Disagree

Figure 1. Online Learning is Following Current Condition

Figure 1 showed that the percentage of students who chose strongly agree was 41,4\%, agree was $55,5 \%$, and disagree was $3,4 \%$. The highest percentage was in agree category. It indicated that most of the students have been applying online learning during COVID-19 pandemic. Khan., et al (2021) believed that e-learning technology enables easy information access of study from any geographical location which is not possible in case of conventional face to face-learning.

2. Online learning helps the smooth process of lectures 58 tanggapan

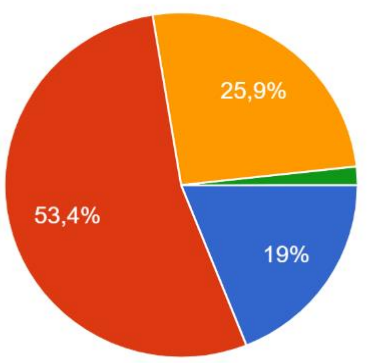

Strongly Agree

Agree

Disagree

Strongly Disagree

Figure 2. Online Learning helps the smooth process of lectures

Figure 2 asking if online learning helps the smooth process of lectures showed that the percentage of students who chose strongly agree was $19 \%$, agree was $53,4 \%$, disagree was $25,9 \%$, and strongly disagree was $1,9 \%$. It indicated that some of the students agree that online learning helps smooth process of lecture. Djamdjuri and Kamilah (2020) stated that teaching and learning online activities which utilizes various kinds of technology as learning media so that teaching and learning is carried out properly and smoothly. 


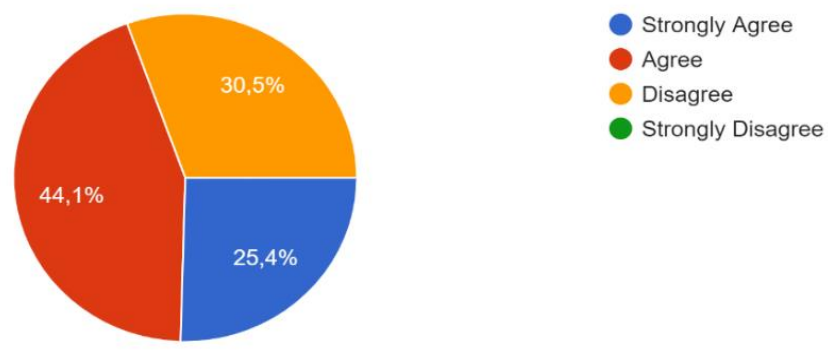

Figure 3. Burdened with Quota Online

Figure 3 showed that the percentage of students who chose strongly agree was 25,5\%, agree was $44,1 \%$, and disagree was $30,3 \%$. We got a very large percentage $(69.1 \%)$ when combining the students' answer of agree and strongly agree. It can be concluded that the students need extra financial burden for internet quota. Similar to Naserly (2020) who also found that the use of some apps like using cloud zoom meeting for online learning has the disadvantage of wasteful internet quota.

4. Signal quality hinders me in online lectures

59 tanggapan

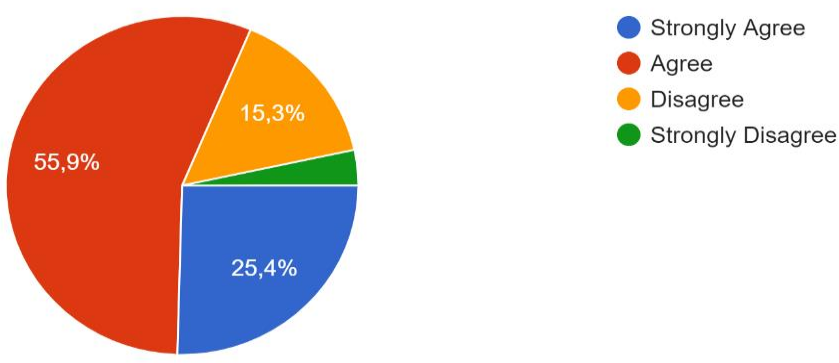

Figure 4. Signal Quality hinders in online lectures

Figure 4 showed the analysis of question number 4 regarding signal quality in online lectures. The percentage of students who chose mostly agree was $55.9 \%$, strongly agree was $25.4 \%$, disagree was $15,3 \%$ and strongly disagree was 3,4\%. It revealed that the students find signal difficulties in doing online learning. They reported that they were sometimes unable to attend the class during online classes due to network issue, error connection, poor audio, and video quality (Nambiar, 2020). 
5. The suitability of online course material with the syllabus

58 tanggapan

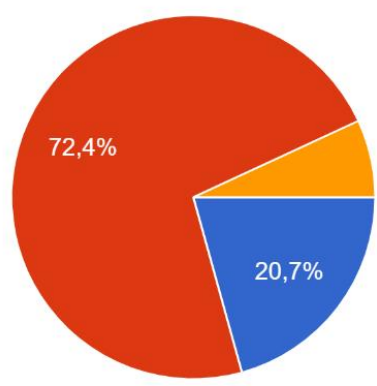

Strongly Agree

Agree

Disagree

Strongly Disagree

Figure 5. The suitability of online course material with syllabus

Figured 5 about the suitability of online course material with syllabus showed that $20,7 \%$ of students chose strongly agree, $72,4 \%$ students chose agree, and 6,9\% chose disagree. This analysis informed us that mostly teaching learning online in STT-Migas was suitable with syllabus. Appropriate lecture materials will affect student learning outcomes (Khoza, 2013)

6. I understand the material provided by the lecturer during online lectures 59 tanggapan

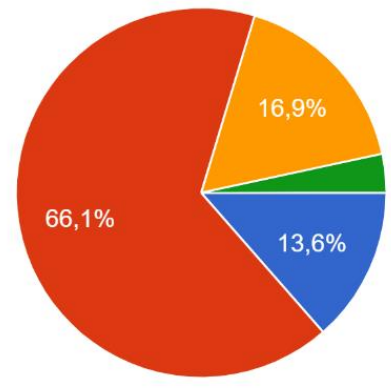

Figure 6. Understand the material provided by the lecturer in online lectures

In the sixth questions regarding understand material provided by the lecturer during online learning, $13,1 \%$ students chose strongly agree, $66,1 \%$ students chose agree, $16,9 \%$ students chose disagree, and 3,4\% students chose strongly disagree. It can be inferred that more than half of the students understood the material better. 


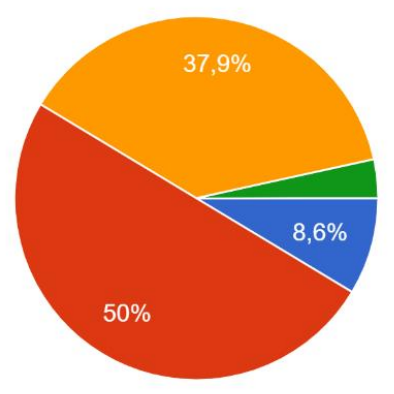

Strongly Agree

Agree

Disagree

Strongly Disagree

Figure 7. Difficulty to handle time in online learning

Figure 7 about the question difficulty to handle time to teach online informed that 5 students or $8,6 \%$ chose strongly agree, 29 students or $50 \%$ chose agree, 22 students or $37,9 \%$ chose disagree, and 2 students or 3,4\% chose strongly disagree. In this question, the most dominant answer was agree; the students encountered difficulties in managing lecture time.

8. Difficulty communicating with lecturers during online lectures

59 tanggapan

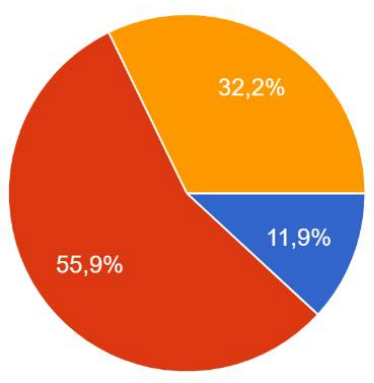

Strongly Agree

Agree

Disagree

Strongly Disagree

Figure 8. Difficulty communicating with lectures during online lectures

Figure 8 about difficulty communicating with lectures during online lectures showed that 7 students or 11,9\% answered strongly agree, 33 students or 55,9\% answered agree, and 19 students or $32,2 \%$ answered disagree. It indicated that the students got difficulty in communicating with the lecture. 
9. Difficulty finding references or reading material during online lectures

59 tanggapan

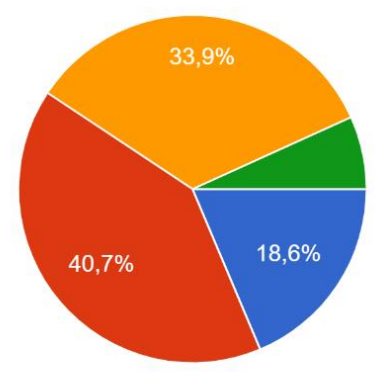

Strongly Agree

Agree

Disagree

Strongly Disagree

Figure 9. Difficulty finding references or reading material in online learning

Figure 9 about difficulty finding references or reading material during online learning described that 11 students or 18,6\% answered strongly agree, 24 students or 40,7\% answered agree, 20 students or $33,9 \%$ answered disagree, and 4 students or 18,6\% answered strongly disagree. It can be inferred that they found difficulty in finding reference or reading material during online learning.

10. Difficulties in doing assignments during online lectures 59 tanggapan

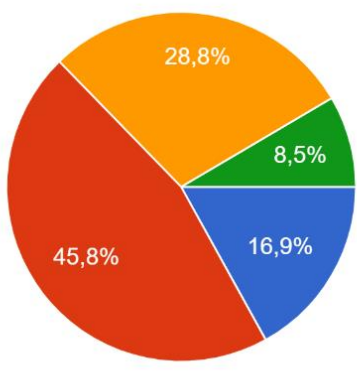

Strongly Agree

Agree

Disagree

Strongly Disagree

Figure 10. Difficulty in doing assignment during online lectures

Based on the Figured 10 about difficulty in doing assignment during online lectures, we discovered that $16,9 \%$ students chose strongly agree, $45,8 \%$ students chose agree, $28,8 \%$ students chose disagree, and 8,5\% students chose strongly disagree. From the analysis we concluded that it was difficult for the students to do assignment. 


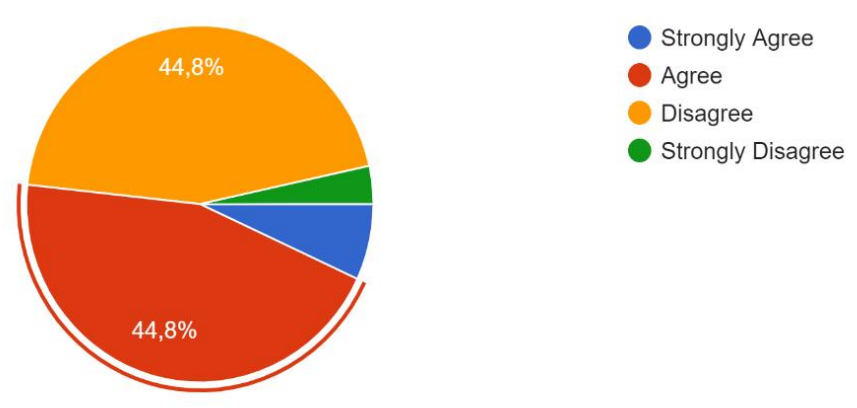

Figure 11. Difficulty using online applications

In the eleventh question about difficulty using online application, the students chose strongly agree was $6,9 \%$, the students chose agree was $44,8 \%$, the students chose disagree was $44,8 \%$, and the students chose strongly disagree was 3,4\%. Based on these results, we found that 26 students were agree that the online application was difficult while 26 students were disagree about it.

12. Trouble collecting assignments during online lectures 59 tanggapan

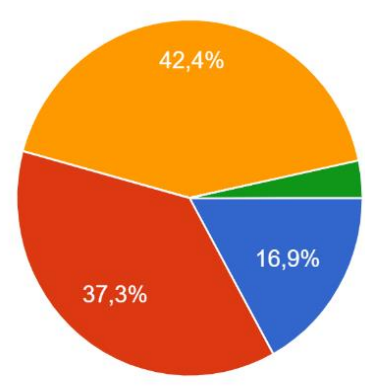

Strongly Agree

Agree

Disagree

Strongly Disagree

Figure 12. Trouble collecting assignments during online lectures

Based on the Figured 12 about trouble collecting assignments during online lectures in doing assignment during online lectures, 10 students or $16,9 \%$ chose strongly agree, 22 students or $37,3 \%$ chose agree, 25 students or $42,4 \%$ chose disagree, and 10 students or $16,9 \%$ chose strongly disagree. It concluded that the students did not have any trouble in collecting assignment. For more details, all questions and the frequency of student answers can be seen in table 1. 
Table 1. The Result of Students Perception of Online Learning

\begin{tabular}{|c|c|c|c|c|}
\hline & \multicolumn{4}{|c|}{ Category } \\
\hline & SA & A & $\mathrm{D}$ & SD \\
\hline 1. Online learning is following current conditions & $41,4 \%$ & $55,2 \%$ & $3,4 \%$ & $0 \%$ \\
\hline 2. Online learning helps the smooth process of lectures & $19 \%$ & $53,4 \%$ & $25,9 \%$ & $1,7 \%$ \\
\hline 3. I am burdened with the quota for online lectures & $25,4 \%$ & $44,1 \%$ & $30,5 \%$ & $0 \%$ \\
\hline 4. Signal quality hinders me in online lectures & $15,3 \%$ & $55,9 \%$ & $25,4 \%$ & $3,4 \%$ \\
\hline 5. The suitability of online course material with the syllabus & $20,7 \%$ & $72,4 \%$ & $6,9 \%$ & $0 \%$ \\
\hline $\begin{array}{l}\text { 6. I understand the material provided by the lecturer during online } \\
\text { lectures }\end{array}$ & $13,6 \%$ & $66,1 \%$ & $16,9 \%$ & $3,4 \%$ \\
\hline 7. I find it difficult to handle the time to teach online & $8,6 \%$ & $50 \%$ & $37,9 \%$ & $3,4 \%$ \\
\hline $\begin{array}{l}\text { 8. Difficulty communicating with lecturers during online } \\
\text { lectures }\end{array}$ & $11,9 \%$ & $55,9 \%$ & $32,2 \%$ & $0 \%$ \\
\hline $\begin{array}{l}\text { 9. Difficulty finding references or reading material during online } \\
\text { lectures }\end{array}$ & $18,8 \%$ & $40,7 \%$ & $33,9 \%$ & $6,8 \%$ \\
\hline 10. Difficulties in doing assignments during online lectures & $16,9 \%$ & $45,8 \%$ & $28,8 \%$ & $8,6 \%$ \\
\hline 11. Difficulty using online applications & $6,9 \%$ & $44,8 \%$ & $44,8 \%$ & $3,4 \%$ \\
\hline 12. Trouble collecting assignments during online lectures & $16,9 \%$ & $37,3 \%$ & $42,4 \%$ & $3,4 \%$ \\
\hline $\begin{array}{ll}\text { SA }: & \text { Strongly Agree } \\
\text { A } & : \text { Agree } \\
\text { D } & \text { : Disagree } \\
\text { SD } & \text { Strongly Disagree }\end{array}$ & & & & \\
\hline
\end{tabular}

This discussion was derived from the data analysis that explained in the previous section. Based on the findings, the results of this study showed that the most items chosen in three questions were item 4,5 , and 6 . The students believed that online learning mode provided them flexibility to study at the time convenient to the learner. Therefore, necessary measures should be adopted for improving the quality of online learning to help with better learning of students during the phase of Covid-19 pandemic. In other side, online learning was carried out in the COVID-19 pandemic, as well as the institutional difficulties that students faced, such as good internet connectivity, financial issues, and the introduction of online learning for students. This finding is in line with (Sujarwo et al., 2020), in their results showed that online learning has been well accepted by the students, they found to be inclined toward online learning tools interact with each other and educator as well. Although have negative factors such as lack of financial supports and internet access availability.

\section{CONCLUSION}

This result of this study indicated that online learning technology enabled students to access easy information leading to positive attitude formation of students towards it. The study affirmed the usefulness of online learning such as ease of study from any geographical location 
which is not possible in case of conventional face to face-learning, suitability with the syllabus and understand material clearly. They considered online learning to be very helpful, although not entirely efficient such as trouble collecting assignment, poor connectivity, burdened with quota online etc. For future researcher who have the same interest to find out students' perception on the effect of online learning during Covid-19, the result of this study is expected to lead the next researcher who conduct a similar topic of research as the reference or comparison that might relevant to their researchers. Furthermore, they are expected to focus their study on more rigorous data analysis method, involve more subjects and contrasting more variables.

\section{REFERENCES}

Amir, M. F., Fediyanto, N., Rudyanto, H. E., Nur Afifah, D. S., \& Tortop, H. S. (2020). Elementary students' perceptions of 3Dmetric: A cross-sectional study. Heliyon, 6(6). https://doi.org/10.1016/j.heliyon.2020.e04052

Djamdjuri, Dewi Suriyani \& Kamilah, Atiyatul. (2020). 11 ; 2. WHATSAPP MEDIA IN ONLINE LEARNING DURING COVID-19 PANDEMIC, 14(2), 69-74.

Green, H., \& Hannon, C. (2007). Their Space: Education for a digital generation. Young People Are Spending Their Time in a Space Which Adults Find Difficult to Supervise or Understand (DEMOS), 1-81.

Hasan, N., \& Khan, N. H. (2020). ONLINE TEACHING-LEARNING DURING COVID-19 PANDEMIC : STUDENTS'. October.

Khan, M. A., Nabi, M. K., Khojah, M., \& Tahir, M. (2021). Students 'Perception towards ELearning during COVID-19 Pandemic in India : An Empirical Study. 1-14.

Khoza, S. B. (2013). Learning Outcomes as understood by 'Publishing Research' facilitators at a South African university. Mevlana International Journal of Education, April, 1-11. https://doi.org/10.13054/mije.13.09.3.2

Nambiar, D. (2020). The impact of online learning during COVID-19 : students ' and teachers 'perspective. 8(2). https://doi.org/10.25215/0802.094

Naserly, M. K. (2020). Implementasi Zoom, Google Classroom, Dan Whatsapp Group Dalam Mendukung Pembelajaran Daring (Online) Pada Mata Kuliah Bahasa Inggris Lanjut. Journal of Chemical Information and Modeling, 4(2), 155-165. https://jurnaldikpora.jogjaprov.go.id/index.php/jurnalideguru/article/view/129

Nasution, A. K. P., \& Ahmad, N. Q. (2020). STUDENT PERCEPTIONS OF ONLINE LEARNING DURING THE COVID-19 PANDEMIC. Jurnal As-Salam, 4(2), 195-204. https://doi.org/10.37249/as-salam.v4i2.219 
Rodriguez, M. C., Ooms, A., \& Montañez, M. (2008). Students' perceptions of onlinelearning quality Given comfort, motivation, satisfaction, and experience. Journal of Interactive Online Learning, 7(2), 105-125.

Sari, W. P., Pramesti, D., \& Kusuma, A. I. (2020). Student's perception of online learning in pandemic. Proceding “International Webinar on Education 2020,” 201-207.

Singh, V., \& Thurman, A. (2019). How Many Ways Can We Define Online Learning? A Systematic Literature Review of Definitions of Online Learning (1988-2018). American Journal of Distance Education, 33(4), 289-306.

https://doi.org/10.1080/08923647.2019.1663082

Sujarwo, S., Sukmawati, S., Akhiruddin, A., Ridwan, R., \& Suharti Siradjuddin, S. S. (2020). An Analysis of University Students' Perspective On Online Learning in The Midst of Covid-19 Pandemic. Jurnal Pendidikan Dan Pengajaran, 53(2), 125. https://doi.org/10.23887/jpp.v53i2.24964

Susila, H. R., Qosim, A., \& Rositasari, T. (2020). Students 'Perception of Online Learning in Covid-19 Pandemic : A Preparation for Developing a Strategy for Learning from Home. November. https://doi.org/10.13189/ujer.2020.082240 